\title{
Retoriese kritiek en die interpretasie van die Ou Testament
}

\author{
H.J.M. (Hans) van Deventer \\ Vakgroep Teologie \\ Skool vir Basiese Wetenskappe \\ Potchefstroomse Universiteit vir CHO \\ Vaaldriehoekkampus \\ VANDERBIJLPARK \\ E-pos: bybhjmvd@puknet.puk.ac.za
}

\begin{abstract}
Rhetorical criticism and the interpretation of the Old Testament

Modern history of Biblical interpretation presents us with two basic approaches to the text of the Bible, viz. historical and literary approaches. This article proposes rhetorical criticism as a process of interpretation that analyses both the historical and literary features of a text. After a short overview of the modern use of the term, especially within the field of Biblical interpretation, this article investigates various "forms" of rhetorical criticism as proposed by scholars working in the fields of general literary theory, a well as Biblical (Old and New Testament) interpretation. The article concludes by proposing a form of rhetorical criticism for interpreting texts from the Old Testament.
\end{abstract}

\section{Inleidend}

Die interpretasie van die Bybel binne 'n akademiese konteks veronderstel onder andere 'n wetenskaplik verantwoordbare metodologie, wat terselfdertyd kan dien as toerusting vir studente met die oog op hulle interpretasie van die Bybel vir besondere beroepseise. Die geskiedenis van Bybelinterpretasie oor die afgelope twee eeue dui op die gebruik van interpretasiemetodes wat hoofsaaklik onder twee noemers (benaderings) tuisgebring kan word, naamlik historiese metodes en literêre metodes. Sedert die opkoms van die literêre benadering tot Bybelinterpretasie vanaf die middel van die twintigste eeu, was voor- en teenstanders van hierdie benaderings dikwels betrokke in hewige debatvoering oor die geldigheid al dan nie van hierdie benaderings. Op eie bodem is die laaste woorde in hierdie debat blykbaar nog nie gespreek nie (vgl. die gesprek tussen Le Roux [1996] en Prinsloo [1996]). 
Gedurende die afgelope dekade of wat het daar egter ook al hoe meer stemme begin opgaan vir ' $n$ meer holistiese benadering tot Bybelinterpretasie waarin gepoog word om sekere elemente van die historiese en literêre benaderings met mekaar te versoen (vgl. op eie bodem die werk van Jonker, 1996). Hierdie artikel probeer om 'n metode te ontwikkel wat erns maak met sowel die literêre as die historiese dimensies van die Bybelteks. Vanweë die teoretiese aard van die projek wat hierdie artikel onderlê, sowel as die teoretiese aard van die stof wat behandel word, word nie voorbeelde van praktiese toepassings ingesluit nie. Die metode wat ontwikkel word, word op grond van die uiteensetting wat hieronder volg, omskryf as retoriese kritiek.

Die uiteensetting begin met 'n verwysing na Bybelwetenskaplikes se herontdekking van retoriese kritiek in die tweede helfte van die twintigste eeu. Daarna word die ontwikkeling van verskillende vorme van retoriese kritiek in die Bybelwetenskappe onder die loep geneem. Vanuit hierdie oorsig word laastens 'n voorstel gemaak met betrekking tot 'n "metode" vir die retorieskritiese interpretasie van die Ou Testament.

\section{Die twintigste-eeuse renaissance van retoriese kritiek in die Bybelwetenskap ${ }^{1}$}

Die gebruik van die benaming retoriese kritiek in die bestudering van die $\mathrm{Ou}$ Testament kan teruggevoer word na die presidensiële rede van James Muilenburg voor die Society of Biblical Literature in 1968. Muilenburg het naamlik in reaksie gekom teen die vormkritiese benadering se historiese inslag, omdat hierdie benadering nie genoeg erns sou gemaak het met die teks self nie. Muilenburg het hierdie reaksie en die gepaardgaande klem op die teks as sodanig getipeer as retoriese kritiek (vgl. Muilenburg, 1992:57).

Sedert 1968 is wyd uiteenlopende navorsing egter onder die noemer "retoriese kritiek" gedoen (vgl. Watson \& Hauser, 1994). In navolging van Muilenburg se reaksie op die historiese inslag van die vormkritiese benadering het baie van sy navolgers retoriese kritiek gaan reduseer tot die beskrywing van 'n hele aantal stilistiese kenmerke in 'n teks (vgl. die kritiek van Mack, 1990:13). In teenreaksie op hierdie "formalisering" van retoriese kritiek is daar in die jongste tyd in die interpretasie van die Ou Testament groter klem geplaas op die respons van die leser op retoriese strategieë in die teks. Vervolgens word gelet op enkele vorme van retoriese kritiek.

1 Hierdie artikel word beperk tot die moderne era. Vir 'n oorsig oor die Klassieke vorme van retoriek word verwys na Kennedy (1980). 


\section{Vorme van retoriese kritiek}

In haar werk wat handel oor 'n sosio-retoriese benadering tot eksegese en meer spesifiek die eksegese van die Ou Testament ${ }^{2}$, maak Hens-Piazza (1996:19) die volgende raak opmerking aangaande retoriese kritiek: “... what one does when conducting a rhetorical analysis requires specification".

Hierdie "spesifikasie" oftewel verbesondering is noodsaaklik, omdat daar enersyds baie vorme van retoriese kritiek bestaan en andersyds gebeur dit dat navorsers met verskillende metodologiese vertrekpunte sonder meer die benaming retoriese kritiek gebruik om hulle interpretasie-"metode" te omskryf 3 . Om 'n duideliker beeld te kry van die verskillende vorme van retoriese kritiek word eerstens gelet op die gebruik van hierdie benaming binne die algemene literatuurwetenskap.

\subsection{Retoriese kritiek in die algemene literatuurwetenskap}

In retoriese kritiek gaan dit volgens die litertuurwetenskaplikes Stevens en Stewart (1987:27) veral oor die ondersoek na die doel van die literêre werk en hoe die gehoor beweeg word tot hierdie (meestal morele) doel4. 'n Nadere ontleding van Stevens en Stewart se definisie van retoriese kritiek maak die omvangrykheid van hierdie benadering duidelik. Wanneer gepraat word van die doel van 'n literêre werk, word dikwels verwys na die doel van die outeur (vgl. Kennedy, 1980:4) binne 'n historiese konteks (dus 'n saak wat lê op die terrein van historiese kritiek - agter die teks). Op grond van Stevens en Stewart se beskrywing is dit verder duidelik dat die gehoor (lesers) ook 'n prominente plek in retoriese kritiek beklee (dus op die vlak van die resepsie van die teks - voor die teks). Laastens dui die "hoe" in die genoemde beskrywing van retoriese kritiek daarop dat daar in die teks self iets opgesluit lê wat van belang is vir retoriese kritiek. Hierdie omvangrykheid van retoriese kritiek word soos volg deur Welch (1990:5) beskryf: "Classical rhetoric ... persists partly because it takes account of all the possible uses of written and spoken language ... [it] concerns itself with all the manifestations of discourse."

2 Vgl. Robbins (1996) vir 'n sosio-retoriese benadering vanuit 'n Nuwe-Testamentiese perspektief.

3 Vgl. in hierdie verband die werk van Trible (1994) enersyds met die werk van Patrick en Scult (1990) andersyds.

$4 \quad$ Hierdie definisie verskil nie in wese van die volgende definisie wat Kennedy (1984:3) vanuit die Bybelwetenskappe vir retoriek gee nie: "Rhetoric is that quality in discourse by which a speaker or writer seeks to accomplish his purposes ... [t] he writers of the books of the New Testament had a message to convey and sought to persuade an audience to believe it ..." (my kursivering HJMvD). 
Die vele fasette wat ter sprake kom by retoriese kritiek het daarom tot gevolg gehad dat 'n groot aantal vertakkinge binne hierdie veld ontstaan het (vgl. Foss [1989] se beskrywing van hierdie vertakkinge binne die algemene literatuurwetenskap). Hierdie vertakkinge in die algemene literatuurwetenskap het meestal ontstaan deurdat navorsers die klem geplaas het op een van die drie fokuspunte van retoriese kritiek (outeur, teks of leser).

'n Ontleding van Foss (1989) se weergawe van die verskillende vorme van retoriese kritiek binne die algemene literatuurwetenskap toon aan dat daar nie een bepaalde vorm van retoriese kritiek bestaan nie. Foss (1989:4) bied 'n breë definisie van retoriek: "rhetoric means the use of symbols to influence thought and action" (kursivering deur Foss). Hierdie simbole kan 'n wye verskeidenheid vorme aanneem - ook die vorm van 'n geskrewe teks.

Foss (1989:26) wys verder daarop dat alhoewel die ideaal 'n holistiese benadering sou wees wat al die moontlike veranderlikes van die retoriese artefak in ag neem, so ' $n$ allesomvattende benadering nie moontlik is nie. Daarom moet die navorser fokus op geselekteerde aspekte in die retoriese proses. Hierdie aspekte hou verband met verskillende elemente in die proses, naamlik die konteks, die boodskap en die outeur (rhetor).

'n Studie wat fokus op die konteks werk vanuit die vraagstelling na die verband tussen die retoriese artefak en die konteks daarvan. 'n Studie waarin die artefak (teks) self die fokus is, sentreer in die probleemstelling van hoe die boodskap 'n bepaalde realiteit vir die gehoor en die outeur skep. 'n Laaste fokusterrein, naamlik op die outeur, poog om 'n antwoord te vind op die vraag wat die retoriese artefak omtrent die outeur openbaar. Foss (1989:27) maak vervolgens die belangrike opmerking dat geeneen van hierdie fokusterreine in isolasie van die ander twee terreine bestudeer kan word nie. Daar is altyd wisselwerking tussen die elemente van konteks, boodskap en outeur.

Die onderskeid wat Foss tref tussen die drie groepe van retoriese kritiek wat afsonderlik fokus op die konteks, die boodskap en die retor is nie bedoel as waterdigte skeidings nie. Daar bestaan nie 'n vorm van retoriese kritiek waarin die fokus net op een van die genoemde terreine (groepe) kan val nie. Aan die ander kant is dit ook duidelik dat daar binne die algemene literatuurwetenskap nie 'n holistiese vorm van retoriese kritiek bestaan waarin alle aspekte gelyke aandag ontvang nie. Dit is dus nodig dat die navorser duidelik sal maak met watter vorm van retoriese kritiek hy / sy werk en hoe ander vorme van retoriese kritiek op daardie vorm inspeel.

Die verwerkliking van retoriese kritiek binne die algemene literatuurwetenskap wys daarop dat die hoofdoel van retoriese kritiek die bestudering van oorredende strategieë ter bereiking van oorredende doelwitte is. Die oorredende strategieë word ondersoek deur die ontleding van die simbole wat gebruik word, 
asook die konstruering van die werklikheid op 'n bepaalde wyse. Retoriese kritiek word dus aangewend vir die beter verstaan van 'n artefak (bv. 'n teks) binne 'n bepaalde sosiale konteks. 'n Verdere gevolgtrekking aangaande retoriese kritiek binne die algemene literatuurwetenskaplike siening is dat die proses van retoriese kritiek nie beperk kan word tot 'n bepaalde aspek in die proses nie. Die aspekte van konteks, boodskap (teks) en outeur speel elkeen 'n rol in retoriese kritiek. In verskillende vorme van retoriese kritiek is dit egter telkens 'n ander aspek wat sentraal staan. In die metode wat hieronder aan die hand gedoen word vir die interpretasie van die Ou Testament, gaan die aspek van die boodskap (teks) sentraal staan.

Die voorafgaande het veral betrekking op die bestudering (ontleding) van die oorredende strategieë in 'n teks. Daarnaas moet die bereik van oorredende doelwitte ook ontleed word om te bepaal of die retoriese handeling geslaag het in hierdie opsig. Cornelius (1998) het in hierdie verband 'n model ontwikkel vir die bestudering van 'n Bybelteks wat voortbou op die standaarde vir die evaluering van 'n retoriese handeling wat Campbell (1982) daargestel het. Wanneer die metode wat hieronder voorgestel word vir die retoriese ontleding van Ou-Testamentiese tekste aan die orde kom, sal na hierdie aspek teruggekeer word.

Met hierdie afleidings in gedagte, gaan vervolgens gekyk word na die realisering van retoriese kritiek in die bestudering van die Bybel.

\subsection{Retoriese kritiek in die Bybelwetenskap}

\subsubsection{Retoriese kritiek in Nuwe-Testamentiese studies 5}

\subsubsection{Ouer vorme van retoriese kritiek in Nuwe-Testamentiese studies}

In die verlede het daar ' $n$ merkbare verskil bestaan tussen sommige Ou- en Nuwe-Testamentici se gebruik van die term retoriese kritiek. Trible $\mathbf{6}$ se bydrae as Ou-Testamentikus vergelyk goed met wat die Nuwe-Testamentikus Du Toit (1992:469) beskryf as "ouer studies" in die retoriese analise van die Bybel. Hierdie "ouer studies" het "dikwels bloot op die stilistiek en by name op stylfigure gekonsentreer". Alhoewel die beskuldiging nie deurgaans van die werk van Trible geld nie, skiet haar studie wel tekort indien dit vergelyk word met $\mathrm{Du}$ Toit se beskrywing van nuwere studies vanuit die retoriese kritiek en die klem

$5 \quad$ Hierdie afdeling gee nie 'n uitgebreide bespreking van retoriese kritiek in Nuwe-Testamentiese studies nie (vgl. in hierdie verband onder andere die werk van Botha, 1991). Dit sou egter nie moontlik wees om retoriese kritiek in die Ou Tesament apart te sien van ontwikkelinge in hierdie verband binne die Nuwe-Testamentiese wetenskap nie. Vgl. ook Amador (1998) vir 'n meer resente oorsig van "retoriese kritieke" vanuit 'n Nuwe-Testamentiese perspektief.

$6 \quad$ Vgl. onder andere Trible (1994). 
wat daarin gelê word op "die analise van effektiewe kommunikasie" (Du Toit, 1992:469; vgl. ook Foss, 1989:4).

Die bestudering van retoriek in die Nuwe Testament is in die verlede veral gekenmerk deur die aansluiting daarvan by die Klassieke retoriek. Die klassifikasie van drie tipes (openbare) kommunikasiehandelinge (forensies, deliberatief en demonstratief) ${ }^{7}$ en die vyf dele van die retoriese proses (ontdekking, rangskikking, gestaltegewing, memorisering en aanbieding) (vgl. Du Toit, 1992:466-467; Trible, 1994:9) is op veral die briefliteratuur van die Nuwe Testament van toepassing gemaak (vgl. Kennedy, 1980:130). Hierdie toedrag van sake sou egter ook daartoe lei dat "allerlei akrobatiese toere onderneem [is] ... en ... die Bybelteks in skemas ingeforseer [is] waarin dit nie hoort nie" (Du Toit, 1992:469).

Die aansluiting wat die retories-kritiese bestudering van die NuweTestamentiese tekste vind by die klassieke retoriek is volgens Kennedy (1984: 10) histories geregverdig, vanweë die algemeen aanvaarde en gebruikte retoriese konvensies gedurende die tyd waarin die Nuwe Testament tot stand gekom het ${ }^{8}$. Retoriese kritiek soos dit oor die algemeen binne Nuwe-Testamentiese studies toegepas is, was die naspeur en beskrywing van die gebruik van die algemeen erkende retoriese tegnieke wat gedurende die eerste eeu n.C. in gebruik was. Die samevatting van die doel van hierdie benadering deur Kennedy (1984:12) is veelseggend: "The ultimate goal of rhetorical analyses ... is the discovery of the author's intent and of how that is transmitted through a text to an audience".

Hierdie "ontdekking van die outeur se doel" word beskryf in terme van die Klassieke retoriek, wat soms daartoe lei dat die eksterne kategorieë van die Klassieke retoriek op die Bybelteks afgeforseer word. 'n Verdere punt van kritiek teen hierdie siening van retoriese kritiek is dat dit in die verlede vasgevang bly, sonder om 'n daadwerklike bydrae te maak tot die verstaan van die teks binne 'n nuwe situasie. Laastens is dit duidelik dat hierdie doel soos uitgespel deur Kennedy swaar steun op 'n literêre teorie wat erns maak met die bedoeling van die outeur, asof daardie bedoeling heeltemal bepaalbaar is ${ }^{9}$.

7 Vir breed uitgewerkte voorbeelde van hierdie drie retoriese "genres" in die Nuwe Testament, kyk Kennedy (1984).

$8 \quad$ Patrick en Scult (1990:57-79) het die forensiese kategorie van Klassieke retoriek ook op enkele narratiewe gedeeltes uit die Ou Testament van toepassing gemaak.

9 Hirsch (1988:254-263) is een van die min literêre kritici wat steeds hierdie standpunt verdedig. Vir die toepassing van Hirsch se onderskeiding tussen betekenis (meaning) en beduidenis (significance) in Bybelintepretasie, kyk Kaiser (1994:41-44). Ná die bydraes van Derrida en Barthes tot die literêre teorie is 'n ongekwalifiseerde standpunt insake die bedoeling van die outeur nie meer houdbaar nie (vgl. Lodge, 1988:253). 
Uit die voorafgaande word gesien dat retoriese kritiek, soos beskou deur NuweTestamentici, nie bly vassteek by stilistiek nie, maar erns maak met die moontlike antieke vorme van retoriek wat in die Nuwe Testament opgesluit is. Wanneer hierdie praktyk egter op 'n ander vlak vergelyk word met retoriese kritiek soos toegepas deur Ou-Testamentici soos Trible, kan aangetoon word dat Nuwe-Testamentici, wat binne hierdie kategorie van retoriese kritiek werk, hulle kollegas in Ou Testament nie so ver voor is nie.

Volgens Trible (1994:26) hou Muilenburg se "kanon" die volgende in: "rhetoric signifies the art of composition; the method involves close reading of texts; the purpose is to discover authorial intent. The emphases recall classical rhetoric and literary-critical theory" (my kursivering - HJMvD).

Alhoewel die klem op ander plekke geplaas word (byvoorbeeld "close reading" as metode) is die ooreenkoms met die Nuwe-Testamentici se weergawe van retoriese kritiek ooglopend. Die negatiewe van albei bogenoemde benaderings tot retoriese kritiek is dat albei in die verlede vasgevang bly en by name by die "doel (intensie) van die outeur". In die woorde van 'n ander NuweTestamentikus, Wuellner (1987:462), is albei benaderings vanweë hierdie feit "formalized, and functionless, and contextless". Hierdie kritiek is deur Botha (1991:180-240) in sy retoriese lesing van Romeine 13:1-7 verwerk. Botha (1991:181-185) wys ook op ander resente Nuwe-Testamentiese studies wat hierdie kritiekpunte verdiskonteer het.

Die siening van die taak van retoriese kritiek, soos verwoord deur Kennedy en Muilenburg, word deur Botha (1988:13) beskryf as slegs die eerste vlak van die diskoers. Die tweede vlak van diskoers wat hiermee moet saamgaan is "the rhetoric of our interpretation of these texts within our social and historical situation" (Botha, 1988:15 - kursiversing deur Botha; vgl. Wuellner, 1987:242). Hierdie voorstel van Botha is 'n uitbouing van die voorbehoude wat Wuellner met betrekking tot Muilenburg en kie se siening van retoriese kritiek het. Wuellner (1987:448) stel byvoorbeeld: "Rhetorical criticism of literature takes the exegete of biblical literature beyond the study of the theological or ethical meanings of the text to something more inclusive than semantics and hermeneutics".

Hierdie artikel gaan poog om, terwyl die winspunte van die "ouer" sienings aangaande retoriese kritiek (vgl. Muilenburg en Kennedy) in gedagte gehou word, terselfdertyd erns te maak met die nuwe fokus wat Wuellner en andere aan hierdie rigting verleen het. Daar moet dus tot 'n mate erns gemaak word met die huidige konteks waarbinne die Bybel gelees word.

'n Literêre kritikus wat 'n voorstel en uitgebreide toepassing vir die retorieskritiese bestudering van Nuwe-Testamentiese tekste daargestel het, is George A. Kennedy (1984). Vervolgens word kortliks gelet op Kennedy se model vir 
retoriese kritiek (vgl. Botha [1991:181-185] vir 'n meer uitgebreide oorsig van die ontwikkeling van retoriese kritiek in die Nuwe-Testamentiese studieveld). Alhoewel hierdie voorstel ietwat verouderd is en gebreke bevat, soos wat hierbo aangedui is, kan dit steeds van hulp wees in die uitwerk van 'n "metode" vir die retories-kritiese lees van die Bybel (vgl. Botha [1991:209] en die Postmodern Bible [PMB] [1995:150-156] wat ook Kennedy se model as vertrekpunt neem).

Kennedy (1984:3) spreek in die eerste plek kritiek uit teen die verskraling van retoriese kritiek tot aspekte van styl. Hy gee daarom die volgende, meer omvattende siening van retoriese kritiek, maar merk op dat daar ten tye van sy skrywe nie 'n bepaalde metodologie aan retoriese kritiek gekoppel is nie: "Rhetorical criticism takes the text as we have it ... and looks at it from the point of view of the author's ... intent, the unified results, and how it would be perceived by an audience" (Kennedy, 1984:4).

Vervolgens behandel Kennedy die vyf dele waarop retoriek berus (invention, arrangement, style, memory, delivery), maar hierdie beredenering word nie hier weergegee nie. Vir hierdie artikel is dit egter belangrik om te let op die vyf "stappe" of fases wat Kennedy (1984:33-38) voorstel vir die beoefening van retoriese kritiek.

- Eerstens word die retoriese eenheid / eenhede van 'n werk bepaal. Meestal is die retoriek van die groter eenheid saamgestel uit die retoriek van die kleiner eenhede. Elke retoriese eenheid moet 'n begin, middel en einde hê (Kennedy, 1984:33). Die retoriese eenheid word bepaal deur op te let na tekens van begin en afsluiting (inclusio) in die teks (Kennedy, 1984:34).

- Tweedens word die retoriese situasie(s) van die retoriese eenhede bepaal. Hierdie retoriese situasie stem volgens Kennedy (1984:34) grootliks ooreen met die Sitz im Leben van vormkritiek. Die vertrekpunt is dat diskoers tot stand kom vanweë 'n bepaalde situasie wat die diskoers ontlok. Kennedy (1984:35) gebruik die begrip "exigence" om 'n situasie aan te dui waarbinne 'n individu (of groep) opgeroep word om te reageer.

- Die derde fase in die retoriese proses is die identifikasie van die vorm van retoriek (deliberatief, juridies of epidikties) wat gebruik word (Kennedy, 1984:36). Die elemente wat eie is aan die bepaalde vorm van retoriek word ontleed.

- Die vierde fase behels die ondersoek na die organisasie van die teks en die styl wat in die diskoers gebruik word (Kennedy, 1984:37). Tydens hierdie fase word bepaal hoe die retor stilistiese aspekte aanwend om die argument uit te bou. 
- In die laaste fase van Kennedy (1984:38) se voorstel met betrekking tot die praktyk van retoriese kritiek word die retoriese eenheid in die lig van die voorafgaande ontleding in sy geheel beskou om te bepaal tot watter mate die diskoers suksesvol was in die aanspreek van die retoriese "exigence".

Vanuit die basiese teoretiese onderbou vir retoriese kritiek wat uit Kennedy se argument verkry word, sal daar hieronder 'n eie "metode" vir retoriese kritiek ontwikkel word. Die verwerkliking van retoriese kritiek binne hierdie lyn van Nuwe-Testamentiese studies maak dus meer erns met die konteks van die retoriese artefak. Een van die stappe in Kennedy (1984:34) se proses van retoriese kritiek hou direk verband met die bepaling van die retoriese situasie waarin die teks spreek. Daar bestaan egter twee leemtes in die vorm van retoriese kritiek wat Kennedy ontwikkel. Die eerste leemte is dat hierdie vorm van retoriese kritiek oorwegend werk met die klassieke kategorieë van retoriese kritiek, sonder om veel kennis te neem van ontwikkelinge wat daarop voortbou. Die tweede leemte is dat hierdie vorm van retoriese kritiek nie tot dieselfde mate as byvoorbeeld Trible se vorm van retoriese kritiek erns maak met die stilistiese aspekte in die teks nie. Die positiewe in hierdie benadering (die aandag wat aan die retoriese situasie [konteks] verleen word) sal dus aangevul moet word deur enersyds kennis te neem van resente ontwikkelinge op die gebied van retoriese kritiek, asook deur andersyds meer aandag te gee aan verskillende stilistiese aspekte in die teks.

Vervolgens word gekyk na 'n resente en belangwekkende bydrae tot retoriese kritiek vanuit Nuwe-Testamentiese studies.

\subsubsection{Resente vorme van retoriese kritiek in Nuwe-Testamentiese studies}

Resente vorme van retoriese kritiek beweeg nader aan wat 'n multidimensionele benadering genoem kan word. Een resente studie wat in 'n sekere sin voortbou op die studie van Mack (1990) waarna daar reeds hierbo verwys is, deurdat dit ook erns maak met 'n sosiale konteks waaruit 'n teks voortkom en waaruit dit gelees word, is die werk van Vernon K. Robbins (1996) getiteld Exploring the texture of texts: a guide to socio-rhetorical interpretation $\mathbf{1 0}$.

10 Die belang van Robbins se werk is onder ander in die volgende aspekte geleë: (1) dit is ' $\mathrm{n}$ resente werk op die terrein van retoriese kritiek en Bybelinterpretasie; (2) die werk poog om 'n holistiese benadering tot Bybelinterpretasie daar te stel wat verskillende benaderings tot die teks wil verwerk tot 'n simbiotiese eenheid; (3) alhoewel Robbins vanuit Nuwe-Testamentiese perspektief werk, is daar alreeds Suid-Afrikaanse Bybelwetenskaplikes wat sy werk op OuTestamentiese tekste van toepassing gemaak het (ek dink hier aan die [tot op hede ongepubliseerde] bydraes van Coetzee [1997] en Viviers [1997] tydens die veertigste jaarkongres van die Ou-Testamentiese werksgemeenskap van Suid-Afrika te Vista, Pretoria. 1997); (4) die feit dat Robbins kontak met Suid-Afrikaanse navolgers het (vgl. Robbins, 1996:ix-x) kan moontlik daartoe lei dat sy werk in ons land nagevolg sal word; (5) tydens die jaarvergadering van die Society of Biblical Literature in San Francisco (1997) is een van die 
Hierdie werk gaan verder as die werk van Mack omdat Robbins bo en behalwe die sosiologiese dimensie ook erns maak met ander dimensies (textures) van die teks.

Robbins (1996:3) stel die omvattenheid van sy benadering daarin dat aandag gegee word aan verskillende dimensies (textures) van die teks. Die volgende dimensies word onderskei (ter wille van duidelikheid word die Engelse benaminge behou): inner texture, intertexture, social and cultural texture, ideological texture en sacred texture. Robbins (1996:5) stel nie 'n vaste metode voor nie, maar laat die invalshoek van die navorser die bepalende faktor wees. 'n Navorser wat byvoorbeeld konsentreer op die teks as sodanig sal begin by die ontleding van die inner texture, terwyl 'n navorser wat 'n histories-kritiese vertrekpunt verkies, sal begin by die ontleding van die intertexture. Die enigste metodologiese vereiste wat Robbins (1996:6) verder stel, is dat die navorser bo en behalwe sy / haar ontleding van daardie dimensie van die teks wat hy / sy as invalshoek verkies, nog twee verdere dimensies van die teks moet ontleed. Sodoende kan 'n blik verkry word op talle fasette waarop ' $n$ teks in die lewe van mense funksioneer.

Die ontleding van die inner texture van 'n teks sluit in geheel nou aan by "close reading" (vgl. Robbins, 1996:37) en gaan nie verder as die data wat in die teks self opgesluit is nie (Robbins, 1996:36). Die bydrae van Trible waarna hierbo verwys is, sal goed inpas binne die ontleding van hierdie dimensie van die teks. Die volgende dimensie van ' $n$ teks wat 'n rol speel by interpretasie en waarna Robbins (1996:40) verwys, is wat genoem word intertexture. Daaronder word verstaan 'n teks se representasie of verwysing na fenomene in die wêreld "buite" die teks, byvoorbeeld historiese gebeure, gebruike, waardes, instellings ens. Die derde groot dimensie van 'n teks is wat Robbins (1996:71) beskryf as die sosiale en kulturele texture wat daarop gemik is om die lesers aan te moedig om bepaalde sosiale en kulturele posisies, in plaas van ander, in te neem (vgl. Robbins, 1996:72).

Die vierde dimensie van die teks wat Robbins bespreek, is wat hy noem die ideological texture (vgl. Robbins, 1996:95) en wat fokus op die sosiale, kulturele en individuele posisionering en perspektief van skrywers en lesers. As sodanig staan die bestudering van hierdie dimensie van 'n teks lynreg teenoor die bestudering van die inner texture van 'n teks waar die fokus nie op die vooroordele van skrywer of leser is nie, maar op die teks self. By die bestudering van die ideologiese dimensie van die teks is die teks net 'n spesiale gas in die interpreterende gesprek (vgl. Robbins, 1996:95, 96). Die vyfde en laaste dimensie van die teks wat van belang is vir 'n sosio-retoriese interpretasie

byeenkomste van die subgroep Rhetoric and the New Testament gewy aan 'n paneelbespreking van die aangehaalde werk van Robbins (vgl. Journal for the Study of the New Testament (1998) 70:69-115 vir die publikasie van hierdie bespreking). 
van die teks is wat Robbins (1996:120) beskryf as die sacred texture en wat ingebed is in die vorige dimensies van die teks wat reeds bespreek is.

Hierdie werkwyse dek egter soveel dimensies van 'n teks dat Robbins (1996:6) self ' $n$ eklektiese gebruikmaking van hierdie werkwyse voorskryf. Daarvolgens word nie aan al vyf die bespreekte dimensies van 'n teks aandag gegee nie, maar slegs aan drie van die vyf. Die positiewe van Robbins se bydrae is dus die erns wat gemaak word daarmee dat 'n retoriese benadering op meer as een dimensie van 'n teks moet fokus. Dit is egter 'n vraag tot watter mate die eerste-eeuse sosiale en kulturele kategorieë wat Robbins opnoem op tekste in die $\mathrm{Ou}$ Testament van toepassing gemaak kan word.

\subsubsection{Retoriese kritiek in Ou-Testamentiese studies}

\subsubsection{Ouer vorme van retoriese kritiek in Ou-Testamentiese studies}

Vroeëre vorme van retoriese kritiek in Ou-Testamentiese studies het die klem laat val óf op die teks, óf op die leser. Daar is merkbaar minder klem laat val op die konteks waarbinne 'n diskoers plaasgevind het. Wanneer daar sprake was van die bedoeling van die outeur, dan het daardie bedoeling nie verband gehou met ' $\mathrm{n}$ historiese situasie nie.

As voorbeeld van die eerste rigting (waarin die klem op die teks geplaas word) kan verwys word na die boek van Trible (1994) Rhetorical criticism. Context, method and the Book of Jonah. Die volgende stelling, waarna Trible (1994:122) verwys as die "Muilenburg rubic", onderstreep die uitgangspunt van hierdie rigting11: "an appropriate articulation of form-content yields an appropriate articulation of meaning".

Hierdie grondstelling word deur Trible (1994:91-101) in fyn besonderhede ontleed. Die praktyk van retoriese kritiek het vir Muilenburg twee sake behels: die afbakening van die grense van die literêre eenheid en die ontleding van die struktuur van die eenheid om eerstens literêre tegnieke te bepaal, asook om te sien hoe die oorheersende struktuur en die individuele onderdele mekaar aanvul. Hierdie algemene beskrywing word deur Trible (1994:101-106) in die volgende tien "stappe" verder uitgewerk:

- die lees van die teks;

- die lees van wetenskaplike werke oor die teks;

- die inwin van agtergrondinligting aangaande die teks;

- die vertroud raak met retoriese begrippe;

11 Albei voorbeelde waarna hier verwys word, is afkomstig van studente van Muilenburg. 
- die bestudering van die eienskappe van die teks (wat insluit: begin en einde; herhaling; diskoerstipes; opbou en struktuur; ontwikkelingsgang; karakteruitbeelding; sintaksis en partikels);

- die beskrywing van die struktuur;

- die vertaling van die teks met behoud van dieselfde antal woorde as in Hebreeus;

- die gebruik van merkers in die aanduiding van prominente eienskappe in die teks;

- die interpretasie van die struktuurmerkers;

- die korrelering van bevindinge.

Die voorstel van Trible met betrekking tot die retoriese lees van 'n teks kan gekritiseer word vir die uitsluitlike aandag wat sy aan teksimmanente aspekte gee. Die positiewe van Trible se benadering is egter juis die sorgvuldige wyse waarop sy konsentreer op elke moontlike stilistiese aspek in die teks. Ongelukkig bly die werk van Trible beperk tot die stilistiese ontleding van die teks en dit lei daartoe dat Trible se interpretasie kontekslos (en konteksloos) voorkom. In die ontwikkeling van 'n meer omvattende metode vir retoriese kritiek vir Ou-Testamentiese studie, sal die positiewe van Trible se metode (intense aandag aan die teks) aangevul moet word met 'n metode wat ook erns maak met konteks.

Vervolgens word gelet op ' $\mathrm{n}$ ander vroeëre manifestasie van retoriese kritiek in die bestudering van die Ou Testament waarin die klem op teksresepsie val. As voorbeeld word verwys na Patrick en Scult (1990:81-102) se bespreking van die boek Job in hulle boek Rhetoric and Biblical interpretation. Hierdie navorsers beskou hulle vorm van retoriese kritiek ook as 'n uitvloeisel van die werk van Muilenburg en verder as "a logical extension of form criticism" (Patrick \& Scult, 1990:29). Trible (1994:47) meen egter dat hierdie vorm van retoriese kritiek verder gaan as Muilenburg se voorstel.

Die studie van Patrick en Scult wil slegs enkele aspekte van hulle benadering tot retoriese kritiek uitlig. Die sentrale vertrekpunt vir Patrick en Scult is om die teks te verklaar as die beste teks moontlik. Op talle plekke in hulle werk word die woorde "best text" aangetref. Hierdie benadering tot interpretasie is ontleen aan die regsfilosoof Ronald Dworkin se stelling: "Interpret the text as the best text it can be" (Patrick \& Scult, 1990:21). Die siening aangaande die "beste teks" word dan soos volg verder omskryf: "Such an interpretation measures the different meanings a text has had against the interpreter's judgment as to what the text in its entirety ... can communicate".

Hierdie omskrywing maak dit duidelik dat Patrick en Scult wegbeweeg het van retoriese kritiek as die bestudering van stilistiek. Hulle fokus baie meer op die 
rol van die leser in die interpretasie van die teks. Die leser kry egter nie in hierdie vorm van retoriese kritiek 'n vrypas om sy / haar subjektiewe gedagtes op die teks af te forseer nie: "[ $t$ ]he dictum [interprets a text as the best text the text can be] grants the text integrity, even priority in the interpretative act; the interpreter should seek the best text it can be, not the text he or she desires it to be" (Patrick \& Scult, 1990:85) (kursivering van Patrick \& Scult).

Hierdie interpretasie deur die leser is verder nie beperk tot die huidige leser nie, maar sluit in die bestudering van vorige interpretasies van die teks. Sodoende word die "tydloosheid" van die teks eerbiedig. Die "beste teks"-benadering gaan nie net terug op die vorige (sekondêre) interpretasies van die teks nie, maar (primêr) tot by "die funksie wat die teks gehad het in sy oorspronklike Sitz im Leben" (Patrick \& Scult, 1990:25). In hierdie opsig poog Patrick en Scult dus om steeds aan te sluit by die vormkritiese rigting.

In hierdie vorm van retoriese kritiek word baie min aandag aan stilistiese aspekte gegee. In 'n poging om die teks en die konteks (verlede, sowel as huidig) by mekaar uit te bring, bly die ontleding van vormlike aspekte van die teks in die slag. Resente vorme van retoriese kritiek in Ou-Testamentiese studies probeer om konteks, teks en resepsie in die interpretasie te laat saamval.

\subsubsection{Resente vorme van retoriese kritiek in Ou-Testamentiese studies}

Soos wat die geval by Nuwe-Testamentiese studies is, beweeg resente vorme van retoriese kritiek in die Ou-Tesament ook nader aan 'n multi-dimensionele benadering. As voorbeeld van 'n werk wat soos Robbins (1996) en veral Mack (1990) erns maak met die sosiale konteks van die teks, word verwys na die studie van Gina Hens-Piazza (1996) getiteld Of methods, monarchs, and meanings. A sociorhetorical approach to exegesis.

Hens-Piazza (1996:3) wys op die beweging deur Bybelwetenskaplikes na die gebruik van meer as een "metode". In haar studie ondersoek sy hoe retoriese kritiek en sosiaalwetenskaplike ondersoek (social science criticism) sinvol geïntegreer kan word. In haar bespreking van retoriese kritiek word gewys op twee rigtings in hierdie verband: een wat fokus op "praatkuns" en 'n ander wat fokus op "skryfkuns". Hierdie twee rigtings word teruggevoer na die klassieke skrywers (Hens-Piazza, 1996:11-14). Resente eksponente van hierdie twee rigtings is volgens Hens-Piazza $(1996: 15,16)$ onderskeidelik Kennedy (praatkuns) en Muilenburg (skryfkuns). Hens-Piazza vind in die toepassing van haar model nouer aansluiting by Muilenburg.

Met betrekking tot sosiaalwetenskaplike ondersoek word gewys op studies in drie rigtings: sosiale geskiedenis; sosiale stelsels; en sosiale kontekste van geskrifte (Hens-Piazza, 1994:24-25). Die ondersoek van die sosiale wêreld in 
die teks (vertelling) word gedoen aan die hand van Geertz se model van "thick description". Daarvolgens word al die sosiale referente in die vertelling (= die antropologiese veld) van nader bestudeer om die sosiale landskap te ontbloot. Hierdie sosiale landskap is ' $n$ literêre konstruk en nie gelyk te stel met die antieke gemeenskap nie.

In sosioretoriese kritiek word die sosiale elemente wat in die vorm en inhoud van retoriek in die teks gegraveer is, ondersoek (Hens-Piazza, 1996:32). Die metode wat ontwikkel word, behels die volgende:

- Daar word begin by die beskrywing van die sosiale konteks uitgebeeld (referenced) in die vertelling.

- Hierop volg drie stappe in die ontleding van die teks:

- Die sosiale elemente word beskryf (vanuit sosiale studies word hierdie elemente omskryf, sodat die identiteit van 'n karakter in die sosiale wêreld van die teks verstaan word);

- die retoriese grense en struktuur van vertelling word bepaal (lê literêre aspekte bloot);

- die wyse waarop sosiale verskynsels en retoriese elemente in interaksie is, word ondersoek.

Hens-Piazza (1996:156) voer aan dat hierdie projek beoog om 'n verbinding te bewerk tussen historiese en literêre benaderings tot die teks. Hierdie metode word egter nie voorgehou as dié antwoord in Bybelinterpretasie nie. HensPiazza (1996:164) vat dit soos volg saam: “... it cultivates a mode of interpretation which recognizes the legitimacy and contributions of other frameworks".

In haar sosioretoriese lesing van 1 Samuel 14:36-46 kom die sosiologiese aspekte in die teks egter nie baie duidelik na vore nie. Die vorm van retoriese kritiek is nie so fyn soos Trible se voorstel ingestel op stilistiese aangeleenthede nie en maak meer erns met narratologiese ontleding en vertellyne.

\section{4. 'n "Metodiek" vir retoriese kritiek}

$\mathrm{Na}$ aanleiding van die voorafgaande bespreking van verskillende vorme van retoriese kritiek word nou 'n voorstel aan die hand gedoen vir die bestudering van die $\mathrm{Ou}$ Testament. Die "metode" van retoriese kritiek wat voorgestel word in die bestudering van die Ou Testament behels die volgende fases ${ }^{12}$ :

12 Hierdie fases wil nie 'n rigoristiese patroon voorskryf nie, maar wil bloot verskillende aspekte van die retoriese proses beskryf. Daarom word die fases ook nie as "stappe" numeries gerangskik nie. 
- die bepaling van die retoriese eenheid of eenhede;

- die bepaling van die retoriese situasie van elke eenheid;

- die bepaling van retoriese styl (wat retoriese rangskikking insluit);

- die evaluering van die totale retoriese argument.

\subsection{Die bepaling van 'n retoriese eenheid}

'n Retoriese eenheid stem vir Kennedy (1984:33) ooreen met 'n perikoop soos wat die term gebruik word in vormkritiese studies (vgl. ook Mack, 1990:21). Die verskil met vormkritiek lê egter daarin dat retoriese kritiek nie soveel belangstel in die bronne (gemeenskappe) waaruit die teks ontstaan het nie.

Die retoriese eenheid word volgens Kennedy (1984:34) gedefinieer as 'n gedeelte van 'n teks wat 'n onderskeibare begin en einde het en verbind word deur ' $n$ bepaalde handeling of argument. Alhoewel daar in gevalle waar die retoriese eenheid deel vorm van 'n groter eenheid, byvoorbeeld 'n toespraak binne 'n vertelling, kennis gedra moet word van die retoriek van die groter eenheid, meen Kennedy (1984:33) dat die retoriek van groter eenhede dikwels opgebou moet word uit die retoriek van kleiner eenhede.

Botha (1991:210) verwys na 'n ongepubliseerde voordrag van Wuellner waarin ' $n$ retoriese eenheid gedefinieer word as soortgelyk aan ' $n$ literêre eenheid, maar meld verder dat ' $\mathrm{n}$ retoriese eenheid daarop gemik is om die leser deur middel van ' $n$ bepaalde argument te oortuig. 'n Retoriese eenheid word dus uitgeken aan die oortuigings-effek daarvan. Die PMB (1995:150) gee 'n soortgelyke beskrywing van die retoriese eenheid en plaas die klem daarop dat die konteks van die oorredende strategie wat daarop gemik is om die leser te oortuig, kan dien as grense van die retoriese eenheid. Hierdie grense is egter arbitrêr (PMB, 1995:151).

Die bepaling van die grense van die literêre eenheid wat by wyse van retoriese kritiek bestudeer word, is ook een van die twee take wat Muilenburg (1992) aan die ontleder opdra. Die grense van die eenheid word bepaal deur bestudering van die vorm-inhoud $\mathbf{1 3}$ van die teks. Die aanduidings van die grense van 'n literêre eenheid wat in die vorm van 'n teks opgesluit mag lê, sluit in: klimaks, inclusio en chiasme. Die bydrae wat die inhoud maak tot die bepaling van hierdie grense hou verband met "groot motiewe" (great motifs) wat gewoonlik aan die begin van die eenheid aan die orde gestel word en aan die einde van die eenheid opgelos is.

13 Die Muilenburg-skool neem as vertrekpunt dat betekenis opgesluit is in die kombinasie van vorm en inhoud, sonder om een van die twee prioriteit bo die ander te verleen. Hierdie vertrekpunt word weerspieël in die benaming "vorm-inhoud" (form-content) (vgl. Trible, 1994:93). 
Trible (1994:93) bou Muilenburg se omskrywing van die literêre (retoriese) eenheid verder uit en lê klem daarop dat die kriteria van vorm-inhoud die grense van die eenheid bepaal. Daar word ook gemeld dat die bepaling van hierdie eenhede ' $n$ arbitrêre saak is en navorsers mag in hierdie opsig van mekaar verskil omdat die "groot motiewe" wat deur die bestudering van die inhoud blootgelê word, moontlik sal verskil. Die grense wat die vorm van die teks vir die retoriese eenheid bepaal (byvoorbeeld deur middel van inclusio en chiasme), is minder arbitrêr, omdat Trible (1994:92) hierdie stylfigure slegs wil onderskei op grond van bykans verbatim herhalingspatrone in die teks.

Uit die voorafgaande kan die volgende kriteria vir die identifisering van retoriese eenhede vasgestel word:

- die retoriese eenheid moet 'n duidelike begin en einde hê waartussen daar 'n diskoers aangaande ' $n$ bepaalde saak is;

- die begin en einde van die retoriese eenheid moet wat vorm betref, blyke kan gee van (verbatim) herhalingspatrone;

- die diskoers in die retoriese eenheid moet daarop gemik wees om 'n oortuigingseffek op die leser te hê.

\subsection{Die bepaling van 'n retoriese situasie}

Botha (1991:198) meen dat die ontleding van die retoriese situasie binne die proses van retoriese kritiek van fundamentele belang is en gee daarom indringend aandag aan hierdie fase in die retoriese proses (vgl. Botha, 1991:188209). Die belangrikste vraag wat in hierdie opsig beantwoord moet word, is wat die verskil en verband is tussen 'n historiese situasie en 'n retoriese situasie.

Die probleem waarvoor die histories-kritiese benadering te staan gekom het, is dat met betrekking tot die Bybelteks (veral Ou-Testamentiese tekste) daar onvoldoende eksterne bronne beskikbaar is waaruit die historiese situasie afgelei kan word. Enige interpretasie van die bronne wat betrekking het op die historiese situasie kom in wese neer op 'n konstruksie van daardie situasie soos beskou deur die navorser. Dit is dus vanweë die komplekse chaos van gebeure en indrukke op enige gegewe tydstip nie moontlik om 'n re-konstruksie van die werklikheid te maak "soos wat dit in der waarheid was" nie (vgl. Botha, 1991:189). Hierdie optimistiese siening aangaande die objektiewe verstaan en weergee van die werklikheid hou verband met die verouderde wetenskapsopvatting van die logiese positivisme (vgl. Van Huyssteen, 1986:19-22).

Die feit dat die "werklike" historiese situasie nie meer vir die hedendaagse navorser toeganklik is nie, bring egter nie teweeg dat die historiese dimensie van die teks geïgnoreer kan word nie. Botha (1991:191) merk op: “... it will be 
impossible to come up with convincing answers to the questions of the meanings and intentions of these texts if historical considerations are totally disregarded".

Kennedy (1984:34) laat die retoriese situasie baie nou aansluit by die Sitz im Leben van die teks wanneer hy hierdie kategorie vanuit 'n oorwegend historieskritiese rigting (vormkritiek) gebruik om die begrip retoriese situasie te omskryf. Binne die vormkritiek val die fokus op die gemeenskap wat vir die ontstaan van die teks verantwoordelik was, asook die omstandighede waarbinne die teks moontlik tot stand kon kom. Hierdie aansluiting by die vormkritiese tradisie wanneer daar retories-krities gewerk word, word ook waargeneem by Patrick en Scult (1990:92) wanneer daar opgemerk word: "[t]he search for the genre of a book is as productive a source of contextulizing as one could ask for". Hierdie siening stuit egter voor dieselfde probleem as wat hierbo met betrekking tot die histories-kritiese benadering in die algemeen opgemerk is, naamlik dat daar nie 'n objektiewe wyse kan wees waarop hierdie historiese konteks vasgestel kan word nie. Die retoriese situasie kan nie gelykgestel word aan die historiese situasie nie.

Botha (1991:197) neem as vertrekpunt vir die bepaling van die retoriese situasie die volgende: "the rhetorical situation only comes into existence when the exigence [problem to be addressed] of the situation comes into relation with the interest of the rhetor". Die vraagstuk wat betrek word, word eers 'n vraagstuk wanneer die eksterne belange van die outeur in relasie gebring word met die situasie.

Dit blyk dus dat enige retoriese situasie ingebed is in 'n historiese situasie. Die vraagstuk in die retoriese situasie is geskoei op elemente van die historiese situasie. Hierdie elemente is egter nie objektief bepaalbaar nie, maar word slegs geken op grond van die relasie wat ontstaan tussen die belange van die outeur en daardie elemente.

Tot dusver is daar in hierdie onderafdeling aandag gegee aan die omskrywing van die retoriese situasie en die verband tussen die retoriese en historiese situasie. Die volgende stap is om 'n metode te bepaal waarvolgens die retoriese situasie(s) van die verskillende retoriese eenhede beskryf kan word. Die voorafgaande bespreking het aan die lig gebring dat twee aangeleenthede van belang is in die bepaling van die retoriese situasie van ' $n$ geskrewe teks: die (historiese) vraagstuk en die belang van die outeur (wat op sy beurt verband hou met ' $n$ bepaalde [geïmpliseerde] gehoor).

In die bepaling van 'n retoriese situasie vir elke retoriese eenheid word die vertrekpunt van Kennedy (1984:33) gevolg dat die retoriek van die groter eenhede afgelei kan word vanuit die retoriek van die kleiner eenhede. In elke retoriese eenheid moet gepoog word om aan die hand van die volgende prosedure die retoriese situasie te bepaal: 
- Bepaal die probleem wat in die teks belig word.

- Beskryf die belange van die implisiete outeur van die teks.

- Beskryf die implisiete gehoor van die teks.

\subsection{Die bepaling van retoriese styl}

Foss (1989:71) wys daarop dat alhoewel die neo-Aristoteliaanse vorm van retoriese kritiek erns probeer maak het met die effek van die retoriese strategie wat die retor gekies het, daar kritiek teen hierdie rigting ingebring is asof dit verval het in die meganistiese opsomming van (Klassieke) retoriese tegnieke wat sprekers gebruik, sonder dat dit 'n bydrae lewer tot die beter verstaan van die retoriese artefak as sodanig (vgl. Foss, 1989:72-74). Dit is dus belangrik dat die bestudering van die retoriese styl van 'n eenheid moet bydra tot die verstaan van die totale retoriese argument.

Die bepaling van die retoriese styl van 'n retoriese eenheid hou meer in as bloot die beskrywing van stylfigure. So 'n kontekslose beskrywing van die styl van 'n eenheid dring nie deur tot die wese van retoriese kritiek nie (vgl. PMB, 1995:155). Stilistiese aspekte van die retoriese eenheid moet daarom beskou word as "techniques of persuasive discourse and their function is described in the context of the rhetorical situation of the text" (Botha, 1991:231), of soos Mack (1990:21) dit stel: "technique is understood as craft in the service of persuation, not merely as creativity in the interest of cleverness, aesthetic, or the enhancement of mysterious meanings".

Vanuit Trible (1994:102-104) se voorstel met betrekking tot aspekte van die teks wat bestudeer moet word, kan die volgende ses algemene aspekte - wat die bepaling van retoriese styl betref - geïdentifiseer word:

- Die eerste aspek waarna Trible verwys, is die herhaling van woorde, frases en sinne, hetsy in verbatim of aangepaste vorm.

- Tweedens word gelet op die tipe diskoers (byvoorbeeld vertelde of direkte diskoers) om byvoorbeeld vas te stel of daar harmonie bestaan tussen die verteller en sy karakters.

- Derdens word die aandag bepaal by die ontwikkeling in die spanningslyn (plot) van die teks.

- Vierdens word die beskrywing van die karakters in die teks ontleed om vas te stel watter funksie hulle in die teks verrig.

- Vyfdens word die sintaksis in oënskou geneem waardeur bepaal word indien daar afwykings waar te neem is van die "normale" patroon. 
- Laastens kyk die navorser na die partikels in die teks om te bepaal wat hulle funksie en betekenis is.

\subsection{Die evaluering van die totale retoriese argument}

Die voorafgaande drie fases in die proses van retoriese kritiek was gemik op die ontleding van die oorredende strategieë in die teks. Die laaste fase in hierdie proses fokus op die oorredende doelwitte en poog om vas te stel of die oorredende strategieë wat in die bepaalde teks "oopgedek" is, daarin slaag om die oorredende doelwitte te bereik. Wanneer ons te doen het met antieke tekste is hierdie 'n meer komplekse aangeleentheid as wanneer kontemporêre tekste retories-krities ontleed word. Daar bestaan weinig eksterne getuienis wat die ontleder kan help om vas te stel wat die effek van 'n antieke teks op 'n "eerste gehoor" was.

Cornelius (1998:60-65) maak egter 'n voorstel in hierdie verband wanneer sy 'n meetinstrument wat Campbell (1982:152-164) ontwikkel het, aanpas om ook gebruik te word in die bepaling van die effektiwiteit van 'n Bybelteks. Campbell (1982:152) onderskei vier kriteria om in gedagte te hou by die beoordeling van retoriese diskoerse, naamlik die effek-kriterium, die waarheidskriterium, die estetiese kriterium en die etiese kriterium. Cornelius (1998:61-65) herrangskik hierdie kreteria en gee die volgende inhoude daaraan:

- Waarheidskriterium: volgens Campbell (1982:153) hou dit verband met die ooreenkoms tussen die realiteit (reality) soos beskryf in die teks en die realiteit soos beskryf in ander bronne. Cornelius (1998:61) koppel aan hierdie kriterium 'n ondersoek na die relevansie van argumente in die teks, asook die wyse waarop hierdie argumente gerangskik is.

- Estetiese kriterium: volgens Campbell (1982:154) fokus hierdie kriterium op die wyse waarop 'n diskoers effek produseer. Cornelius (1998:62) beoordeel in hierdie verband die skrywer se skepping van 'n omgewing van sosialisering, die skepping van bepaalde kenmerke by die deelnemers aan die sosialiseringsproses en die aanwending van stilistiese strategieë en konvensies.

- Etiese kriterium: Campbell (1982:155) koppel hierdie kriterium aan die beoordeling van die langtermyn-effek van die retoriek op die gemeenskap, sowel as op toekomstige retoriese diskoerse. Cornelius (1998:64) bring hierdie beoordeling in verband met ' $n$ skrywer se oortuigingsmiddele, sy appèl op die gehoor se emosies en sy taalgebruik.

- Effek-kriterium: Hierdie moeilik bepaalbare aspek hou volgens Campbell (1982:152) verband met die reaksie wat die retoriese handeling ontlok. Cornelius (1998:65) hanteer hierdie aspek deur dit in verband te bring met 
die aard van die teks en die prys van deelname (d.i. wat is die rol wat die gehoor moet speel ten einde 'n geslaagde retoriese handeling daar te stel).

Cornelius (1998) pas hierdie kriteria in haar studie toe op Nuwe-Testamentiese briefliteratuur. Omdat die meeste van die teoretiese elemente wat hier genoem word, in die teks self ingebed is, sal hierdie model - met enkele wysigings - ook gebruik kon word in die laaste fase van die interpretasiemodel wat in hierdie artikel vir Ou-Testamentiese tekste voorgestel word.

Die resultate van hierdie beskrywing (fases 1-3) en evaluering (fase 4) van 'n teks kan enersyds nuwe insigte in die teks oopmaak en andersyds bestaande interpretasies bevestig. Sodoende kan hierdie vorm van retoriese kritiek 'n omvattende bydrae lewer tot die verstaan van die Ou Testament binne 'n moderne en steeds veranderende konteks.

\section{Samevattend}

Hierdie artikel poog om op grond van ontwikkelinge binne die veld van retoriese kritiek 'n model vir die interpretasie van die Ou Testament te ontwikkel. Hierdie model verteenwoordig nie 'n finale antwoord op vrae rondom die interpretasie van die Bybel binne 'n akademiese konteks nie. Die bydrae wat dit wil lewer, is enersyds daarin geleë dat dit 'n brug probeer slaan tussen historiese en literêre metodes van Bybelinterpretasie. Andersyds kan hierdie model deur bedienaars van die Woord oorweeg word vir die verklaring van die Bybel met die oog op die praktiese bediening.

\section{Bibliografie}

AMADOR, J.D.H. 1998. Where could rhetorical criticism (still) take us? Scriptura, 67(4):387-404.

BOTHA, J. 1988. On the "reinvention" of rhetoric. (In Coetzee, J.C., red. Koninkryk, Gees en Woord. Huldigingsbundel aangebied aan prof. dr. Lambertus Floor. Pretoria : NG Kerkboekhandel. p. 1-18.)

BOTHA, J. 1991. Reading Romans 13. Aspects of the ethics of interpretation in a controversial text. Stellenbosch : Univerity of Stellenbosch. (D.Th. thesis.)

CAMPBELL, K.K. 1982. The rhetorical act. Belmont, Ca. : Wadsworth.

COETZEE, J.H. 1997. Putting words into the enemy's mouth: The investigation of a rhetorical persuasion strategy in the Psalms. (Unpublished paper delivered at the fourtieth congress of the Old Testament Society of South Africa at Vista Pretoria.)

CORNELIUS, E.M. 1998. The effectiveness of 1 Thessalonians - a rhetorical-critical study. Stellenbosch : Univerity of Stellenbosch. (D.Th. thesis.)

DU TOIT, A.B. 1992. Retoriek, retoriese analise en prediking. In die Skriflig, 26(4):465-477.

FOSS, S.K. 1989. Rhetorical criticism. Exploration and practice. Prospect Heights, Ill. : Waveland Press.

HENS-PIAZZA, G. 1996. Of methods, monarchs, and meanings. A sociorhetorical approach to exegesis. Macon : Mercer University Press.

HIRSCH, E.D. 1988. Faulty perspectives. (In Lodge, D., ed. Modern criticism and theory. A reader. London : Longman. p. 254-263.) 
JONKER, L.C. 1996. On plotting the exegetical-hermeneutical landscape. Scriptura, 59(4):397-411.

KAISER, W.C.

$k y k$ KAISER, W.C. \& SILVA, M.

KAISER, W.C. \& SILVA, M. 1994. An introduction to biblical hermeneutics. Grand Rapids : Eerdsmans.

KENNEDY, G.A. 1980. Classical rhetoric and its Christian and secular tradition from ancient to modern times. London: Croom Helm.

KENNEDY, G.A. 1984. New Testament interpretataion through rhetorical criticism. Chapell Hill : The University of North Carolina Press.

LE ROUX, J.H. 1996. Eksegese is 'n spel. Acta Theologica, 16(1):41-56.

LODGE, D., ed. 1988. Modern criticism and theory. A reader. London : Longman.

MACK, B.L. 1990. Rhetoric and the New Testament. Minneapolis : Fortress Press.

MUILENBURG, J. 1992. Form criticism and beyond. (In House, P.R., ed. Beyond form criticism. Essays in Old Testament literary criticism. Winona Lake : Eisenbrauns. p. 4969.)

PATRICK, D. \& SCULT, A. 1990. Rhetoric and biblical interpretation. Sheffield : Almond Press.

PMB

kyk Postmodern Bible en The Bible and Culture Collective.

POSTMODERN BIBLE (PMB)

kyk Bible and Culture Collective

PRINSLOO, W.S. 1996. Eksegese is 'n spel (sonder reëls?). Acta Theologica, 6(2):21-33.

ROBBINS, V.K. 1996. Exploring the texture of texts. A guide to socio-rhetorical interpretation. Valley Forge : Trinity Press.

STEVENS, B.K. \& STEWART, L.L. 1987. A guide to literary criticism and research. New York : Holt, Rinehart and Winston.

THE BIBLE AND CULTURE COLLECTIVE. 1995. The postmodern Bible. New Haven : Yale.

TRIBLE, P. 1994. Rhetorical criticism. Context, method, and the book of Jonah. (Guides to Biblical Scholarship. Old Testament Series.) Minneapolis : Fortress Press.

VAN HUYSSTEEN, J.W.V. 1986. Teologie as kritiese geloofsverantwoording. Pretoria : Raad vir Geesteswetenskaplike Navorsing.

VIVIERS, H. 1997. "Look up to Yahweh for mercy" - a socio-rhetorical analysis of Psalm 123. (Unpublished paper delivered at the fourtieth congress of the Old Testament Society of South Africa at Vista, Pretoria.)

WATSON, D.F., ed. 1998. Vernon Robbins's socio-rhetorical criticism: A review. Journal for the Study of the New Testament, 70:67-115.

WATSON, D.F. \& HAUSER, A.J. 1994. Rhetorical criticism of the Bible. A comprehensive bibliography with notes on history and method. Leiden : Brill.

WELCH, K.E. 1990. The contemporary reception of classical rhetoric: appropriations of ancient discourse. Hillsdale, NJ : Lawrence Erlbaum Associates.

WUELLNER, W. 1987. Where is rhetorical criticism taking us? Catholic Biblical Quarterly, 49:448-463. 